\title{
Functional and molecular imaging-scintigraphic techniques
}

\author{
Buscombe J. *, Wong B. \\ *Nuclear Medicine, Royal Free Hospital, London UK
}

\begin{abstract}
The development of molecular medicine and our understanding of the processes of disease have been mirrored by the development of molecular techniques for imaging. Most of the current work involves cancer as this is where there is the most extensive knowledge of what happens at a cellular level.

Examples of this include the use of specific agents such as Tc-99m annexin-V to identify apoptosis as soon as 24 hours after administration of cytotoxic chemotherapy and Tc-99m or F-18 RGD peptides to identify active angiogenesis and using imaging to demonstrate the effect anti-angiogenic drugs such as taxanes. PET techniques have also developed form simple F-18 FDG to look at cell metabolism to F-18 FMISO which can identify hypoxic tissue.C-11 methionine amino-acid uptake and $\mathrm{C}-11$ acetate fatty acid metabolism

Receptor imaging has developed from use in neuroendocrine tumours using somatostatin receptors to other hormones such as oestrogen and gastrin. In addition there has been work in the brain and in particular the use of imaging of pre-synaptic dopamine receptors by I-123 Ioflupane
\end{abstract}

\section{Correspondence author:}

\section{Prof J. R. Buscombe}

Nuclear Medicine

Addenbrookes Hospital

Hills Road

Cambridge CB2 0QQ

Email john.buscombe@addenbrookes.nhs.uk

There has been a close and growing relationship between our expansion of knowledge of the molecular basis of disease and our ability to image these processes in-vivo using scintigraphic techniques.

Key words Molecular Imaging, PET, single photon, receptor studies

\section{Introduction:}

The essence of functional and molecular imaging is to look at how tissues function invivo and use those techniques which allow a physiological or pathological process to be identified and assessed by non-interventional means. To assess a function it is vital that the techniques used does not alter that function. For example if looking at renal function a radionuclide renography may be preferable to a contrast IVU as the latter is nephrotoxic and could change the function of the kidney as it passes through. As a consequence most forms of functional imaging at present use isotopic technique based on the von Hevesy tracer principles where the radio-pharmaceuticals used can be in pico-gram concentration and have no pharmacological effect. 


\section{Functional imaging or molecular imaging}

These two terms may be used interchangeably however in the terms of reference of this review The definition used is that functional imaging encompasses all forms of imaging which looks primarily at function but not anatomy. Molecular imaging is a subset of functional imaging and is interested in looking at what occurs at the cell level and not the organ level. Except for the possibility of optical imaging we are not able to use techniques to look at a single cell in vivo but what we can do is look at what is happening to a group of cells which are responding to a stimulus or pathology in a similar way.

\section{Why molecular imaging?}

We are living in times of great revolution in medical thought. Before the decoding of the human genome, and our new understanding of the genetic individuality of each person, medicine relied on the gross pathological response as seen in the majority of patients. This is reflected in many chemotherapy drug regimes where evidence is collected in randomized multi-centre trials and the answers will tell the oncologist that what on average gives the best overall result (1-3). Though this may be useful to the largest number of patients the oncologist ends up treating not individuals but populations. For example all patients with a stage III invasive ductal breast cancer treatment may undergo a similar treatment regime. The data to justify a particular regime is obtained from a range of randomized clinical trial often multi-centre in origin and should result in the highest possible number of patients having the best possible response. However there is a flaw in that individuals due to their genetic make -up and the genetic make up of their tumour may respond differently to the same treatment regime. This has been understood in breast cancer and patients are now assessed for oestrogen receptors and HER-2 to allow more precise treatment regimes $(4,5)$. However a further assumption is made in the fact that biopsy material is often only present from one site and it is assumed that all sites of the cancer have molecular characteristics which are identical but we know this is not true as in some patients the primary tumour may be oestrogen receptor positive but metastases may be receptor negative. If we were able to image the patient at the molecular level we could understand better what is happening in that individual patient and also if there is some variation occurring within that patient which would have an effect on treatment.

\section{The Neuroendocrine model.}

We have found that a good example of this has been neuroendocrine tumours (NET). These tumours tend to be slow growing so that patient may take many years to die. During this time the tumour may change its nature and this may be reflected in how it is imaged. There are two main methods for functionally imaging NET invivo. The first method uses the fact that many of these tumours retain an embryological amine uptake mechanism and can be seen with I-123 metaiodobenzyl guanidine (mIBG) with about $60-70 \%$ of patients with NET have uptake of I123 mIBG (6-8). The second method exploits the fact that most of these tumours also have over expression of somatostatin receptors which can be imaged by the use of a radiolabelled octapeptide based on human somatotstatin (In111 pentetreotide) which is positive in about 85$90 \%$ of NET (7-11).

In a review of 149 NET patients imaged with both I-123 mIBG and In-111 pentreotide we found that I-123 mIBG was positive in $63 \%$ of patients and In-111 pentreotide was positive in $79 \%$ of patients (12). However in $12 \%$ of patients both the radiopharamceuticals were positive but indentifying tumours within the same patient some of which accumulated both tracers and some which accumulated only I-123 mIBG or In-111 pentetreotide (Fig 1) so using in-vivo molecular imaging we were able to 
identify three different population of tumour cells within the same patient (thos positive with both agents and those positive with one of the two agents. This may be of great importance in deciding optimal therapy as a variety of treatments may be needed to effectively treat this patient's tumour.

\section{I-123 mIBG SPECT of the liver}

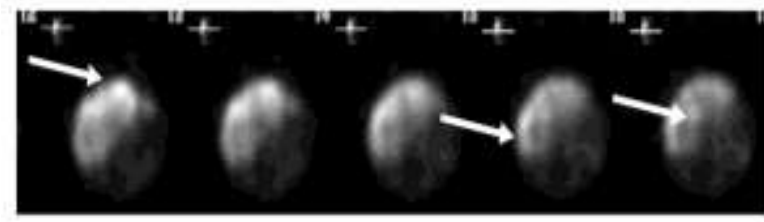

In-111 pentetreotide of the liver

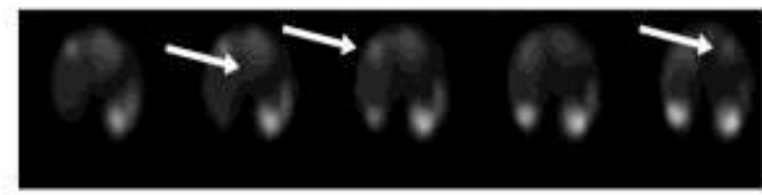

Fig 1. 56 year old women with a mid-gut carcinoid showing different lesions (arrowed) within the liver seen on single photon emission computed tomography (SPECT) of the liver with I-123 mIBG and In-111 pentetreotide.

This has stimulated further research into this rare tumour type. There are 5 subclasses of somatostatin receptor and whilst In-111 pentetreotide has good affinity for sub-type 2 it does not localize other subtypes well (13). There is another commercially available somatostatin based radiopharmaceutical and that is Tc-99m depreotide. Thus has affinity for receptor subtypes 2, 3 and 5. It has been know that NET of fore-gut origin are the ones most often found to be In-111 pentetreotide negative. In a small series of fore-gut NET which had no or poor uptake of In-111 pentetreotide it was found that some of these tumours have good uptake of Tc99m depreotide (14, Fig 2) showing that different NET express different somatostain receptor profiles. Again this could have a profound effect on treatment as those tumours only positive on Tc-99m depreotide may not benefit from octreotide based products as these only attach to the type- 2 receptor sub-group.

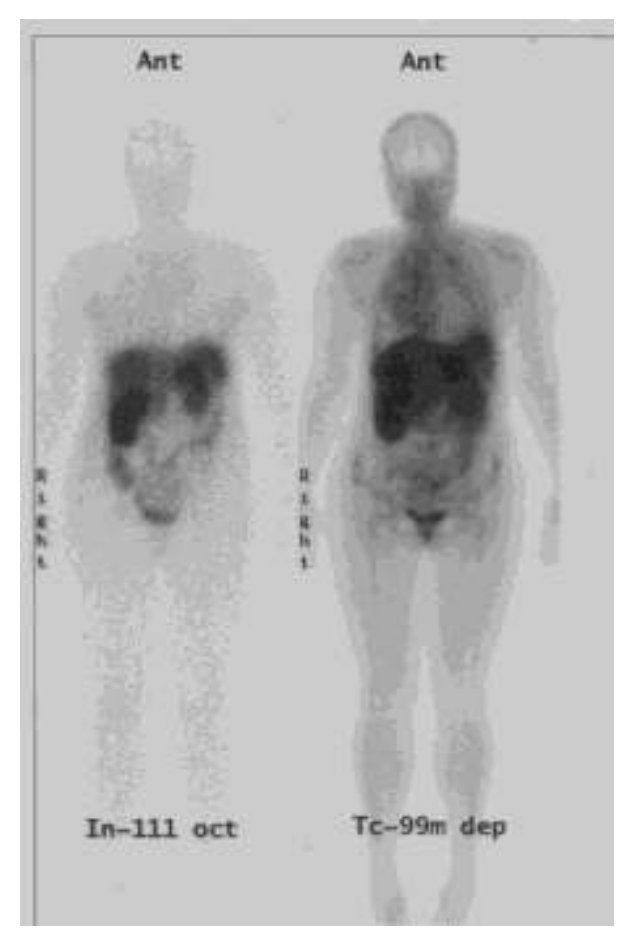

Fig 2. Whole body imaging of a 46 year old man with thymic carcinoid showing poor uptake of In-111 pentetreotide (left hand image) in the lung metastases but good uptake of Tc-99m depreotide (right hand image).

We have not been able to tie these variations in molecular imaging to factors identifiable on immunohistiochemistry until the advent of positron emission tomography (PET). PET allows imaging of high resolution but also high sensitivity making it an ideal, if expensive, molecular imaging method. The normal method of imaging tumours is to use F-18 fluorodeoxyglucose (FDG) which exploits the fact that cancers have a higher cell turnover and metabolic rate than normal tissue and require more glucose then other cells so will have preferential uptake in tumour cells. However in NET F-18 FDG may be of less use as these tumours tend to have a lower metabolic rate and can therefore be negative (15). There is a form of somatostatin receptor imaging that can be used in PET. This combines a peptide octreotate which has higher affinity for the type 2 somatostatin receptor than In-111 pentetreotide 
labelled with Ga-68 a positron emitting metallic isotope (16). In one of our NET patient imaged with both F-18 FDG and Ga-68 octreotate multiple sites of disease was found with F-18 FDG but only one site of disease with Ga-68 octreotate (Fig 3). Further investigation revealed that the tumour sites which were positive for F18 FDG had a high $\mathrm{Ki}-67$ (Ki-67 is an immunohistological test which looks at the proportion of cells in active cell division) whilst the single node positive for Ga-68 octreotate had a $\mathrm{Ki}-67<1 \%$. This could have profound effect on her treatment as cytotoxic chemotherapy may be expected only to have an anti-tumour effect on those tumour sites which have a high Ki-67 and are F-18 FDG positive.
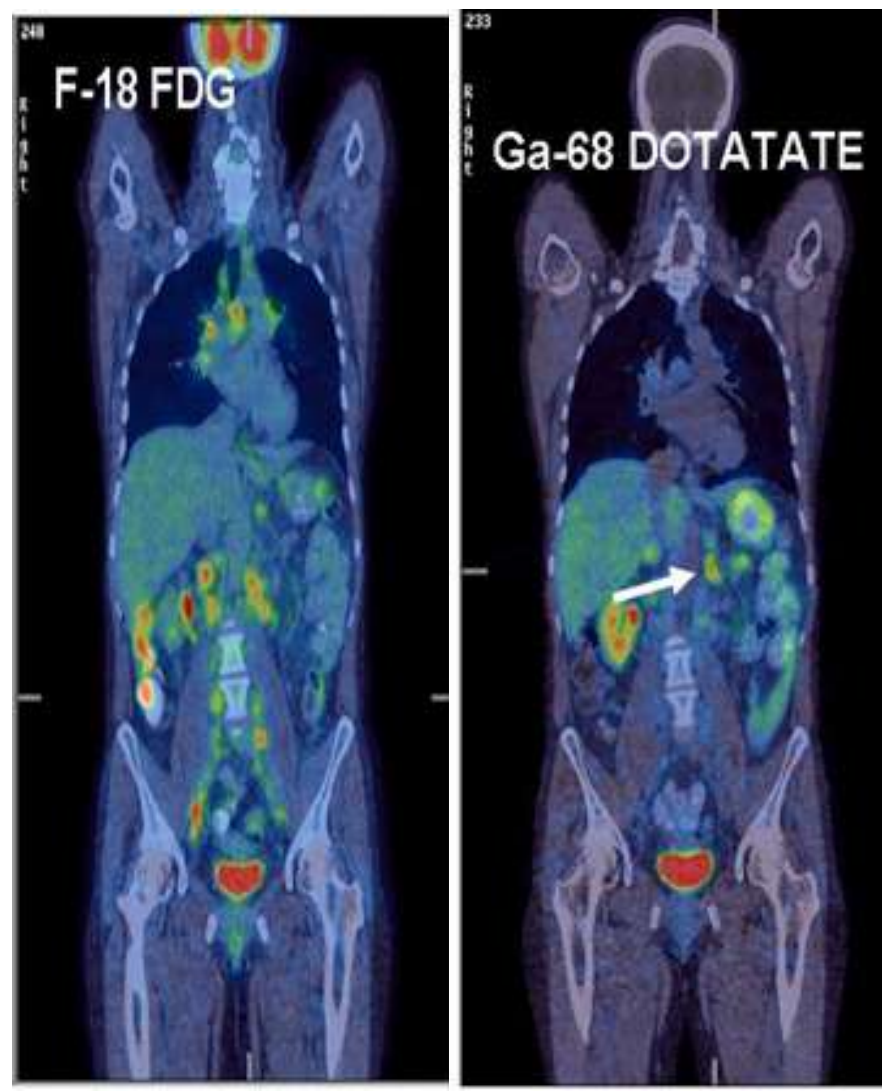

Fig 3. Coronal PET-CT images of a 36 year old women with a fore gut neuroendocrine tumour showing multiple sites of disease on F-18 FDG PET which biopsy showed the Ki-67 to be >15\% and a single node positive on Ga-68 DOTATATE imaging (arrowed) which in biopsy had a Ki-67 of only $1 \%$.

\section{Cell division}

In most cancers cells divide at a faster rate than surrounding tissues. This is important as most cytotoxic chemotherapy drugs disrupt the process of cell division when there is protein production either in mitosis (M phase) or during DNA synthesis (S phase) before mitosis (Fig 4).

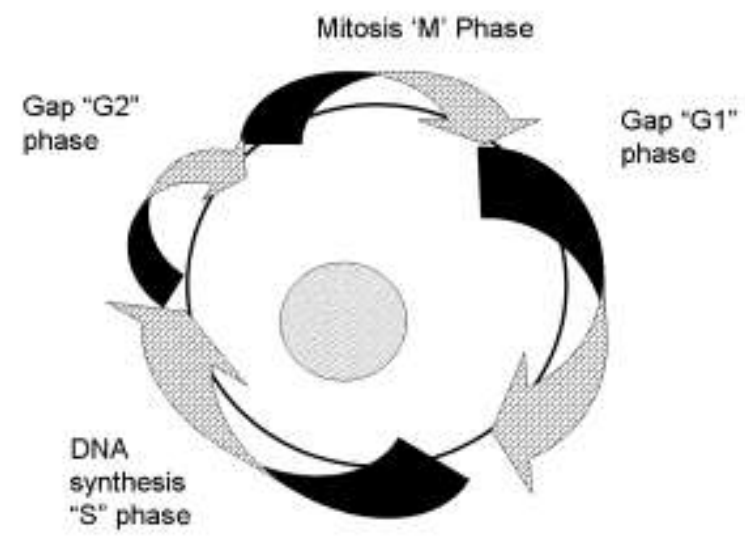

Fig 4 Diagram of the cell cycle most drugs work on the DNA synthesis phase ( $S$ phase).

Therefore it may of use to identify in vivo if cancer cells are activity dividing before giving potentially toxic chemotherapy. The methods most developed in this field are mainly positron emitters and include F-18 fluoro-L-tyrosine (FLT) and C-11 methionine. F-18 FLT is carried into the cell on $\mathrm{S}$ phase tyrosine kinase and has been shown to be an effective may to demonstrate in vivo the action of antiproliferative drugs with reduced uptake of the tracer when the cell cycle is disrupted (17). For example in non small cell lung cancer it was found that F-18 FLT was more specific in determining residual tumour than F-18 FDG as it had no uptake in post treatment inflammation unlike F-18 FDG (18)

C-11 methionine is expensive to make and $\mathrm{C}-11$ only has a 12 minute half life so the chemistry must be performed very quickly incorporating the $\mathrm{C}-11$ into the carbon chain and having a product ready for injection with a few minutes 
(19). It has found most use in brain tumours including those considered benign because normal brain does not undertake mitosis so any abnormal uptake can only occur in dividing cells in the brain which can only occur in the presence of a activity growing neoplastic pathology (Fig 5, 19-21).

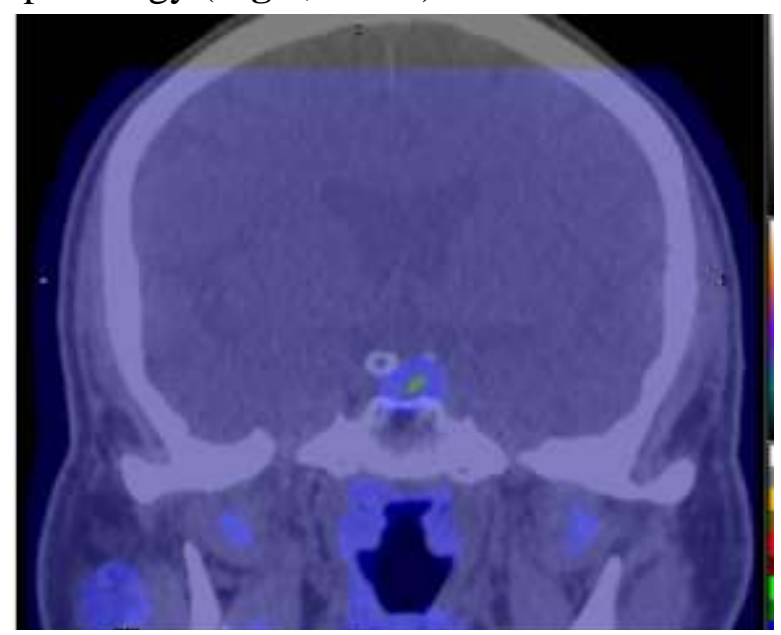

Fig 5. C-11 methionine PET-CT showing uptake into a TSHoma

\section{Apoptosis}

In most tissues cell division and cell destruction is in balance, however in tumours there can be a failure of cell destruction leading to cell immortality, this with increased tumour growth rates then leads to increasing in the size of the cancer. There are two main methods of cell death, immediate (necrosis) or delayed called apoptosis. Most effective treatments of cancer involved induction of apoptosis. Once this process starts it is irreversible and cell death in 10 days is inevitable (22). During apoptosis there is blebbing of the cell wall surface and reversal of the cell wall so that antigen hidden within the cell become exposed. These antigen can be complexed to the protein Annexin-V.

Annexin-V has been labeled with both positron emitters and Tc-99m (23). The single photon methods are cheaper and have been more widely used. It is known that apoptosis commences within 24 hours of exposure to an effective anticancer drug even though cell destruction may be delayed. This introduces a very interesting concept if a Tc-99m annexin- $\mathrm{V}$ scan performed within 24 hours of a single dose of the chosen chemotherapy agent it should only show uptake if that drug will effectively destroy that cancer. Therefore it may be possible to predict within 24 hours in any given drug regime is likely to be successful or not. In a study of patients with Hodgkins it has been shown that if there is uptake of Tc-99m annexin V at 24 hours the same sites will show complete tumour response at 6 months on F-18 FDG PET (24). Further studies on other tumour types are need to confirm these changes, but if these first study results are negative on annexin imaging, this could help reduce the number of patients given chemotherapy drugs without any hope of response.

For example in a study from the Netherlands Tc-99m Annexin V imaging was performed after radiotherapy of bulky lymphoma and chemotherapy of small cell lung cancer (25). In the lymphoma patients there was homogeneous uptake of Tc-99m Annexin-V 24 hours after the first dose of radiotherapy with most patient achieving a complete response. However in some of the patients with small cell lung cancer uptake of Tc-99m annexin V at 24 hours after the first cycle of treatment was patchy and subsequently in these patients there was little or no response to treatment, Similar work has now been developed using PET agents such as F-18 Annexin V (26)

\section{Angiogenesis}

One of the fascinating facts about tumour growth is that as cell growth is disorganized the cells end up further and further from an arterial blood supply and become hypoxic. One of the cells responses to this is to release various substances such as vascular epiderimal growth factor (vEGF) which causes new blood vessels to grow into the tumour mass a process known as angiogenisis. (27-29). Many new anti-cancer treatments have been directed towards this process as the cancer cells are dependent on this process to maintain oxygenation and the removal of the angiogenisis blood supply can lead to tumour necrosis. Simple anti-angiogenic drugs include tholidamide though more modern drugs such as sunitinib or bevacizumab are more effective (30-31). 
It would be useful to have an agent which can identify this process in-vivo so that it can be decided if anti-angiogenic treatment is warranted and also to monitor the effect of treatment. At present the most specific agents identified for this type of imaging are based on RGD (Arginine-Glycine-Aspartate) peptides which have a high affinity for the alpha-V-beta intergens vEGF receptors on the cell wall (32). Work using Tc-99m RGD peptides have shown good localization in a mouse model of human breast cancer which has also shown inhibition of uptake in the presence of taxanes at sites of angiogenisis $(33,34)$ but human studies beyond phase I have not been performed. Newer work looking at PET based products with the option of looking more closely at the microenvironment within the tumour which is possible because of the improved resolution with PET (35). Also it may be possible to combine with MR using the new generation PET-MR machines.

\section{Hypoxia}

Hypoxia is the response of any cell to a reduction of oxygen tension. In the heart it may occur as a result of vascular insufficiency whilst in tumours it may be the result of tumours outgrowing the existing blood supply. There are several consequences of hypoxia. Firstly the cells are unable to burn fatty acids or pryuvate both of which is oxygen dependent. However they can still undergo-anaerobic metabolism of glucose. This process is highly inefficient and as such there is an increased demand for glucose. This increased need for glucose helps to explain why tumours and very ischaemic heart can be avid for F-18 FDG on a PET scan. However uptake of F-18 FDG alone does not in itself confirm the presence of hypoxia as other factors can result in increased uptake of F-18 FDG.

Therefore more specific hypoxia markers have been sought. These have been based on imiadazole esters. These are lipophilic esters which enter the cells but when there is high levels of oxygen in the cell the ester is broken and the hydrophilic components expelled from the cell. Therefore the product is only retained within the hypoxic cell (36). The three main agents used for hypoxia imaging are all ester based and include F-18 fluoromisonidazole (FMISO) Cu-64 diacetyl-bis(N4-methylthiosemicarbazone (ATSM), both PET agents, and a Tc-99m nitroheterocycle (HL91) a single photon agent (36-39).

Imaging hypoxia is important because hypoxic cells do not divide and may show resistance to chemotherapy drugs which act on dividing cells. In addition it would appear that hypoxia inhibits wild p53 an inducer of apoptosis. As radiation therapy requires the production of oxygen radicals as an intermediate step to DNA damage the lack of oxygen reduces the number of such radicals that can be produced reducing the effectiveness of radiation based therapies (40). Imaging will predict those areas of tumour less likely to respond to specific treatments but may do well with anti-angiogenic treatment as their blood supply is already compromised (Fig 6).

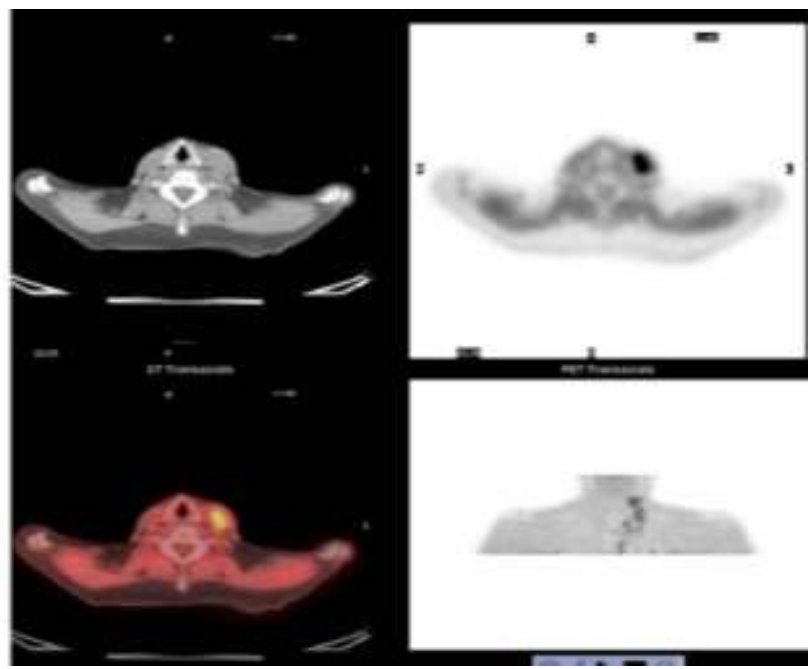

Fig 6. F-18 FMISO PET-CT uptake in metastatic renal cell carcinoma in cervical lymph noded

One specific area of interest has been the use of Tc-99m HL91 in patients with head and neck cancer where hypoxia can significantly reduce the effect external beam radio therapy in a small study there was a good correlation between uptake and retention of Tc-99m HL-91 and poor response to radiotherapy (41). The important 
point about imaging however is that each lesion or area of the tumour can be looked at separately so that in an individual patient some sites will have no uptake of tracer and may respond well whilst other sites with good uptake of these hypoxia agents could be treated by other means such as surgery (41).

In a similar way hypoxia agents could be used to identify areas of heart with critical ischaemia such that an assessment of the volume of myocardium at risk by initiating appropriate intervention and allow an early response to treatment as it may take up to 6 months for myocardium to have a return of function after restoration of a good blood supply (42).

\section{Chemo-resistance}

The drugs used to treat cancer are expensive and have significant amounts of toxicity however it is know that in some patients they have little effect. It has been shown that there are various mechanisms in place which ensure chemoresistance within the patient. The best investigated of these is the multi-drug resistence-1 (MDR1) gene. This codes for a surface P-glycoprotein (PgP) which activity effluxes toxic substance from the cell (41). It has been shown in various studies that Tc-99m MIBI is a substrate for $\mathrm{PgP}$ and fast washout form sites of tumour will predict the presence of $\mathrm{PgP}(44,45)$. This is important as one of the most common effective drugs in breast cancer are the taxanes and they are very sensitive to the presence of $\mathrm{PgP}$ and as a consequence several groups have suggested using cancer washout rates of Tc-99m MIBI to determine if taxanes should be given (46).

\section{Receptor imaging}

The somatostatin based model described at the start of this review shows a receptor based imaging working at its most successful. This has lead to searches for other receptor based systems because not only do they offer the chance of high quality imaging but they may suggest ways forward in terms of specific therapies using either radiolabelled or no radiolabelled agents.CEA The classical target for tumour imaging is carcino-embyronic antigen (CEA) which is over expressed in colon, pancreatic and some breast cancer. This antigen has been exploited by the use of both antibodies and antibody fragments (45-47). The only product to be used commercially was a Fab' labeled with Tc-99m called CEAscan. (49) This product was able to identify nodal metastases from cancer of the colon and was used widely until the advent of F-18 FDG PET, since when it has been withdrawn from the market

There have been further attempts to use this antigen for developing a therapeutic radionuclide therapy for metastatic colon cancer (50). However there seem be significant problems in that there is patchy penetration of the tumour masses by the antibody and at present the most hopeful results seem to be to use a combination of chemotherapy and radiolabelled antibodies (51).

\section{Prostate cancer}

Prostate cancer also has a unique antigen in the prostate specific antigen (PSA). This has been targeted for diagnostic use in North America by an In-111 labelled antibody marketed as "Prostoscint". This has found a specific use in indentifying lymph node disease within the pelvis which is important in small tumours where radical therapy is being considered (52).

PSA is not an ideal antigen to use for radionuclide therapy as it is present on both dead tissue and live cells. A better target is the Prostate Specific Membrane antigen (PMSA) which is present on live prostate and prostatic cancer cells Phase I and some early phase II studies using either Y-90 or Lu-177 have shown some promising results (52). However work has been stalled due to financial issues.

\section{Oestrogen receptors}

Oestrogen is a very tempting target to use on functional imaging. Manipulation of the oestrogen receptor is used in both benign and malignant disease and imaging could be of use. In one interesting study it has been shown that reduction in uptake of F-18 labelled oestrogens had a better correlation with response of breast 
cancer to treatment than use of F-18 FDG as breast tissue during treatment often initiates an inflammatory reaction which results in nonspecific uptake of F-18 FDG (54).

\section{Gastrin receptors}

Gastrin receptors are widely distributed throughout the gastro-intestinal tract however whilst there has been good labeling shown with gastrin or bombesin based peptides one problem has been a significant pharmacological effect even in tracer quantities leading to severe nausea and vomiting $(55,56)$.

\section{Dopamine receptors}

The dopamine system has been the second most successful form of receptor based imaging. Its use however has not been related to cancer but to the diagnosis of Parkinson's syndromes such as Parkinsons's disease and Supra-nuclear palsy.

The product which has been developed commercially is I-123 Ioflupane. This is taken up into the pre-synaptic cells in the basal ganglia. As the uptake is into the pre-synaptic cells anti-Parkinsonian drugs such as L-DOPA can be continued during the imaging procedure which can be important for those patients who become dependent on these drugs for their mobility.

As the Parkinson's syndromes progresses there is first of all loss of uptake of I-123 Ioflupane in the putamen, and then in the basal ganglia, Finally there is cerebral cortical uptake as there is no longer a critical mass of pre-synaptic cells to take up the tracer $(57,58$, Fig 7$)$.
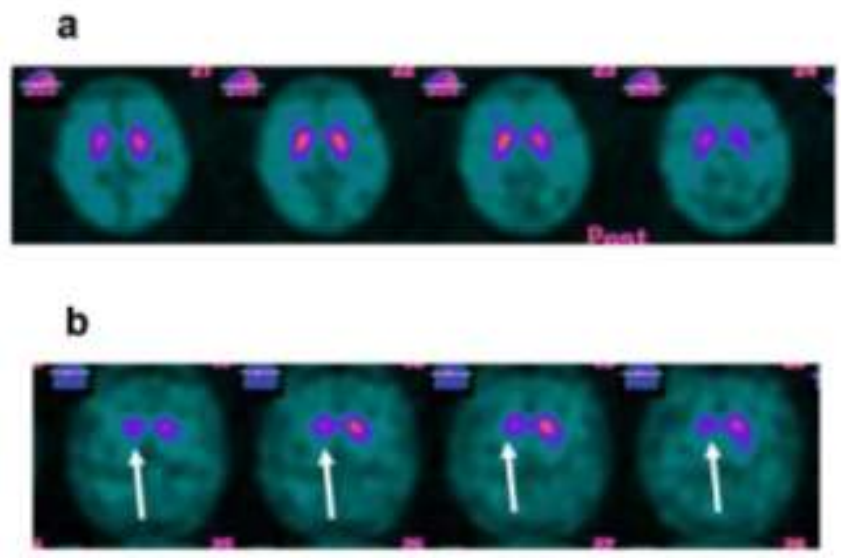

Fig 7 Transverse tomographic I-123 Iopfulpane imaging in a normal subject (a) and a patient with early Parkinson's Disease (b). Note in the abnormal study there is unilateral loss of activity in the right putamen (arrowed).

The main use of this technique is to differentiate true Parkinson's syndromes from drug induced tremor and benign tremor where at least $25 \%$ of cases are still in doubt after clinical assessment but less than 5\% after imaging (59).

More recent work has also shown a positive study in patients with a movement disorder and problems with short term memory suffer caused by Lewy body dementia (60).

\section{Conclusions}

Functional imaging to our knowledge has the ability to design specific imaging tests to exploit disease increase. At present most of the applications are in cancer (Table 1) with some of the methods already available either in clinical practice or human research. As our knowledge of the molecular basis of disease increases these techniques will be applied in other major areas including cardiology and neurology.

\section{References}

1) Seymour MT, Maughan $\mathrm{TS}$, Ledermann JA, Topham C, James R, Gwyther SJ, Smith DB, Shepherd S, Maraveyas A, Ferry DR, Meade AM, Thompson L, Griffiths GO, Parmar MK, Stephens RJ; FOCUS Trial Investigators; National Cancer Research Institute Colorectal Clinical Studies Group Different strategies of sequential and combination chemotherapy for patients with poor prognosis advanced colorectal cancer (MRC FOCUS): a randomised controlled trial Lancet. 370:143-52; 2007. 
2) Posner MR, Hershock DM, Blajman CR, Mickiewicz E, Winquist E, Gorbounova V, Tjulandin S, Shin DM, Cullen K, Ervin TJ, Murphy BA, Raez LE, Cohen RB, Spaulding M, Tishler RB, Roth B, Viroglio Rdel C, Venkatesan V, Romanov I, Agarwala S, Harter KW, Dugan M, Cmelak A, Markoe AM, Read PW, Steinbrenner L, Colevas AD, Norris CM Jr, Haddad RI; TAX 324 Study Group. Cisplatin and fluorouracil alone or with docetaxel in head and neck cancer. N Engl J Med. 357:1705-15; 2007.

3) Sandercock J, Parmar MK, Torri V, Qian W. First-line treatment for advanced ovarian cancer: paclitaxel, platinum and the evidence $\mathrm{Br}$ J Cancer. 87:815-24; 2002.

4) Spigel DR, Burstein HJ. HER2 overexpressing metastatic breast cancer. Curr Treat Options Oncol. 3:163-74; 2002.

5) Spigel DR, Burstein HJ Trastuzumab regimens for HER2-overexpressing metastatic breast cancer. Clin Breast Cancer. 4:329-37; 2003.

6) Feldman JM, Blinder RA, Lucas KJ, Coleman RE Iodine-131 metaiodobenzylguanidine scintigraphy of carcinoid tumors J Nucl Med. 27:1691-6; 1986.

7) Kaltsas GA, Mukherjee JJ, Grossman AB. The value of radiolabelled MIBG and octreotide in the diagnosis and management of neuroendocrine tumours Ann Oncol. 12 2:S47$50 ; 2001$.

8) Nocaudie-Calzada M, Huglo D, Carnaille B, Proye C, Marchandise X Comparison of somatostatin analogue and metaiodobenzylguanidine scintigraphy for the detection of carcinoid tumours Eur J Nucl Med. 23:1448-54; 1996.

9) Krenning EP, Bakker WH, Kooij PP, Breeman WA, Oei HY, de Jong M, Reubi JC, Visser TJ, Bruns C, Kwekkeboom DJ, et al. Somatostatin receptor scintigraphy with indium111-DTPA-D-Phe-1-octreotide in man: metabolism, dosimetry and comparison with
iodine-123-Tyr-3-octreotide J Nucl Med. 33:652-8; 1992.

10) Krenning EP, Kwekkeboom DJ, Bakker WH, Breeman WA, Kooij PP, Oei HY, van Hagen M, Postema PT, de Jong M, Reubi JC, et al Somatostatin receptor scintigraphy with [111In-DTPA-D-Phe1]- and [123I-Tyr3]octreotide: the Rotterdam experience with more than 1000 patients. Eur J Nucl Med. 20: 716-31; 1993.

11) Krenning EP, Kwekkeboom DJ, Oei HY, de Jong RJ, Dop FJ, Reubi JC, Lamberts SW Somatostatin-receptor scintigraphy in gastroenteropancreatic tumors. An overview of European results Ann N Y Acad Sci. 733:41624; 1994.

12) Quigley AM, Buscombe JR, Shah T, Gnanasegaran G, Roberts D, Caplin ME, Hilson AJ. Intertumoural variability in functional imaging within patients suffering from neuroendocrine tumours. An observational, cross-sectional study. Neuroendocrinology. 82:215-20; 2005.

13) Virgolini I, Britton $K$, Buscombe J, Moncayo R, Paganelli G, Riva P In- and YDOTA-lanreotide: results and implications of the MAURITIUS trial. Semin Nucl Med. $32: 148-55 ; 2002$.

14) Tahir S, Kulakiene I, Warbey V, Quigley AM, Srirajaskanthan R, Toumpanakis_C, Hochhuase D, Caolin ME, Buscombe JR The role of $99 \mathrm{mTc}$-depreotide in the imaging of neuroendocrine tumours Nucl Med Commun in press 2008 .

15) Belhocine T, Foidart J, Rigo P, Najjar F, Thiry A, Quatresooz P, Hustinx R Fluorodeoxyglucose positron emission tomography and somatostatin receptor scintigraphy for diagnosing and staging carcinoid tumours: correlations with the pathological indexes p53 and Ki-67. Nucl Med Commun. 23:727-34; 2002.

16) Hofmann $M$, Maecke $H$, Börner $R$, Weckesser E, Schöffski P, Oei L, Schumacher J, Henze M, Heppeler A, Meyer J, Knapp H. 
Biokinetics and imaging with the somatostatin receptor PET radioligand (68)Ga-DOTATOC: preliminary data Eur J Nucl Med. 28:1751-7; 2001.

17) Barthel H, Cleij MC, Collingridge DR, Hutchinson OC, Osman S, He Q, Luthra SK, Brady F, Price PM, Aboagye EO. 3'-deoxy-3'[18F]fluorothymidine as a new marker for monitoring tumor response to antiproliferative therapy in vivo with positron emission tomography Cancer Res. 63:3791-8; 2003.

18) Yap CS, Czernin J, Fishbein MC, Cameron RB, Schiepers C, Phelps ME, Weber WA. Evaluation of thoracic tumors with ${ }^{18} \mathrm{~F}$ fluorothymidine and ${ }^{18} \mathrm{~F}$-fluorodeoxyglucosepositron emission tomography. Chest. 129:393401; 2006.

19) Schober O, Duden C, Meyer GJ, Müller JA, Hundeshagen $\mathrm{H}$ Non selective transport of $\left[{ }^{11} \mathrm{C}\right.$ methyl]-L-and D-methionine into a malignant glioma. Eur J Nucl Med. 13:103-5; 1987.

20) Ogawa T, Shishido F, Kanno I, Inugami A, Fujita H, Murakami M, Shimosegawa E, Ito H, Hatazawa J, Okudera T, et al. Cerebral glioma: evaluation with methionine PET Radiology. 186:45-53; 1993.

21) Torii K, Tsuyuguchi N, Kawabe J, Sunada I, Hara M, Shiomi S Correlation of amino-acid uptake using methionine PET and histological classifications in various gliomas Ann Nucl Med. 19:677-83; 2005.

22) Searle J, Lawson TA, Abbott PJ, Harmon B, Kerr JF An electron-microscope study of the mode of cell death induced by cancerchemotherapeutic agents in populations of proliferating normal and neoplastic cells. J Pathol. 116:129-38; 1975.

23) Blankenberg FG, Katsikis PD, Tait JF, Davis RE, Naumovski L, Ohtsuki K, Kopiwoda $\mathrm{S}$, Abrams MJ, Darkes M, Robbins RC, Maecker HT, Strauss HW In vivo detection and imaging of phosphatidylserine expression during programmed cell death. Proc Natl Acad Sci U S A. 95:6349-54; 1998.
24) Belhocine $T$, Steinmetz $N$, Hustinx $R$, Bartsch P, Jerusalem G, Seidel L, Rigo P, Green A. Increased uptake of the apoptosis-imaging agent $(99 \mathrm{~m}) \mathrm{Tc}$ recombinant human Annexin V in human tumors after one course of chemotherapy as a predictor of tumor response and patient prognosis Clin Cancer Res. 8:2766$74 ; 2002$.

25) Kartachova MS, Valdes Olmos RA, Haas RJM, Hoebers FJP, van Herk M, Verheij M. ${ }^{99 \mathrm{~m}}$ Tc-HYNIC-rb-annexin-V scintigraphy: visual and quantitative evaluation of early treatment-induced apoptosis to predict treatment outcome. Nuc Med Commun 29: 39-44; 2008.

26) Toretsky J, Levenson A, Weinberg IN, Tait JF, Uren A, Mease RC. Preparation of F-18 labeled annexin $\mathrm{V}$ : a potential PET radiopharmaceutical for imaging cell death Nucl Med Biol. 6; 747-52; 2004.

27) Shweiki D, Itin A, Soffer D, Keshet E Vascular endothelial growth factor induced by hypoxia may mediate hypoxia-initiated angiogenesis. Nature. 359:843-5; 1992.

28) Carmeliet P, Dor Y, Herbert JM, Fukumura D, Brusselmans K, Dewerchin M, Neeman M, Bono F, Abramovitch R, Maxwell P, Koch CJ, Ratcliffe P, Moons L, Jain RK, Collen D, Keshert E Role of HIF-1alpha in hypoxiamediated apoptosis, cell proliferation and tumour angiogenesis Nature. 394:485-90; 1998.

29) Tsuzuki Y, Fukumura D, Oosthuyse B, Koike C, Carmeliet P, Jain RK Vascular endothelial growth factor (VEGF) modulation by targeting hypoxia-inducible factor-1alpha--> hypoxia response element--> VEGF cascade differentially regulates vascular response and growth rate in tumors Cancer Res. 60:6248-52; 2000.

30) Diaz-Rubio E. New chemotherapeutic advances in pancreatic, colorectal, and gastric cancers. Oncologist. 9:282-94; 2004.

31) Choueiri TK, Plantade A, Elson $P$, Negrier S, Ravaud A, Oudard S, Zhou M, Rini BI, Bukowski RM, Escudier B. Efficacy of sunitinib 
and sorafenib in metastatic papillary and chromophobe renal cell carcinoma J Clin Oncol. 26:127-31; 2008.

32) Verhoef C, de Wilt JH, Verheul HM Angiogenesis inhibitors: perspectives for medical, surgical and radiation oncology Curr Pharm Des. 12:2623-30; 2006.

33) Janssen ML, Oyen WJ, Dijkgraaf I, Massuger LF, Frielink C, Edwards DS, Rajopadhye M, Boonstra H, Corstens FH, Boerman OC. Tumor targeting with radiolabeled alpha(v)beta(3) integrin binding peptides in a nude mouse model. Cancer Res. 62:6146-51; 2002 .

34) Jung KH, Lee KH, Paik JY, Ko BH, Bae JS, Lee BC, Sung HJ, Kim DH, Choe YS, Chi DY. Favorable biokinetic and tumor-targeting properties of $99 \mathrm{mTc}$-labeled glucosamino RGD and effect of paclitaxel therapy. $\mathrm{J}$ Nucl Med. 47:2000-7; 2006.

35) Battle MR, Goggi JL, Allen L, Barnett J, Morrison MS. Monitoring tumor response to antiangiogenic sunitinib therapy with $18 \mathrm{~F}-$ fluciclatide, an 18F-labeled $\alpha$ Vbeta3-integrin and $\alpha \mathrm{V}$ beta5-integrin imaging agent $\mathrm{J} \mathrm{Nucl}$ Med. 52:424-30; 2011.

36) Rasey JS, Koh WJ, Grierson JR, Grunbaum Z, Krohn KA Radiolabelled fluoromisonidazole as an imaging agent for tumor hypoxia. Int $\mathbf{J}$ Radiat Oncol Biol Phys. 17:985-91; 1989.

37) Koh WJ, Rasey JS, Evans ML, Grierson JR, Lewellen TK, Graham MM, Krohn KA, Griffin TW. Imaging of hypoxia in human tumors with [F-18]fluoromisonidazole Int $\mathrm{J}$ Radiat Oncol Biol Phys. 22:199-212; 1992.

38) Fujibayashi Y, Cutler CS, Anderson CJ, McCarthy DW, Jones LA, Sharp T, Yonekura Y, Welch MJ. Comparative studies of Cu-64ATSM and C-11-acetate in an acute myocardial infarction model: ex vivo imaging of hypoxia in rats Nucl Med Biol. 26:117-21; 1999.

39) Rumsey WL, Cyr JE, Raju N, Narra RK. A novel $[99 \mathrm{~m}]$ technetium-labeled nitroheterocycle capable of identification of hypoxia in heart. Biochem Biophys Res Comm. 193:1239-1246; 1993.

40) Vanselow B, Eble MJ, Rudat V, Wollensack $\mathrm{P}$, Conradt C, Dietz A Oxygenation of advanced head and neck cancer: prognostic marker for the response to primary radiochemotherapy. Otolaryngol Head Neck Surg. 122:856-62; 2000.

41) Van De Wiele C, Versijpt J, Dierckx RA, Moerman M, Lemmerling M, D'Asseler Y, Vermeersch H 99Tc(m) labelled HL91 versus computed tomography and biopsy for the visualization of tumour recurrence of squamous head and neck carcinoma Nucl Med Commun. 22:269-75; 2001.

42) Fukuchi K, Kusuoka $H$, Yutani $K$, Hasegawa S, Nishimura T. Assessment of reperfused myocardium using a new ischaemiaavid imaging agent, technetium-99m HL91: comparison with myocardial glucose uptake Eur J Nucl Med. 25:361-6; 1998.

43) Piwnica-Worms D, Chiu ML, Budding M, Kronauge JF, Kramer RA, Croop JM. Functional imaging of multidrug-resistant Pglycoprotein with an organotechnetium complex. Cancer Res. 53:977-84; 1993.

44) Del Vecchio S, Ciarmiello A, Salvatore M. Wash-out kinetics of $99 \mathrm{mTc}-\mathrm{MIBI}$ and the scintigraphic determination of Pgp expression: reply Eur J Nucl Med. 25:192; 1998.

45) Burak Z, Ersoy O, Moretti JL, Erinç R, Ozcan Z, Dirlik A, Sabah D, Basdemir G The role of $99 \mathrm{mTc}-\mathrm{MIBI}$ scintigraphy in the assessment of MDR1 overexpression in patients with musculoskeletal sarcomas: comparison with therapy response. Eur J Nucl Med. 28:1341-50; 2001.

46) Shih CM, Hsu WH, Huang WT, Wang JJ, Ho ST, Kao A Usefulness of chest single photon emission computed tomography with technetium-99m methoxyisobutylisonitrile to predict taxol based chemotherapy response in 
advanced non-small cell lung cancer. Cancer Lett. 199:99-105; 2003.

47) Sullivan DC, Silva JS, Cox CE, Haagensen DE Jr, Harris CC, Briner WH, Wells SA Jr. Localization of I-131-labeled goat and primate anti-carcinoembryonic antigen(CEA) antibodies in patients with cancer Invest Radiol. 17:350-5; 1982.

48) Behr TM, Becker WS, Klein MW, Bair HJ, Scheele JR, Wolf FG Diagnostic accuracy and tumor-targeting kinetics of complete versus fragmented 99mTc-labeled anticarcinoembryonic antigen antibodies: an intraindividual comparison. Cancer Res. 55:5786s-5793s; 1995.

49) Moffat FL Jr, Vargas-Cuba RD, Serafini AN, Casillas VJ, Morillo G, Benedetto P, Robinson DS, Ardalan B, Manten HD, Clark $\mathrm{KC}$, et al Radioimmunodetection of colorectal carcinoma using technetium-99m-labeled Fab' fragments of the IMMU-4 anticarcinoembryonic antigen monoclonal antibody Cancer. 73:836-45; 1994.

50) Murray JL, Macey DJ, Kasi LP, Rieger P, Cunningham J, Bhadkamkar V, Zhang HZ, Schlom J, Rosenblum MG, Podoloff DA. Phase II radioimmunotherapy trial with $131 \mathrm{I}-\mathrm{CC} 49$ in colorectal cancer. Cancer. 73:1057-66; 1994.

51) El Emir E, Qureshi U, Dearling JL, Boxer GM, Clatworthy I, Folarin AA, Robson MP, Nagl S, Konerding MA, Pedley RB. Predicting response to radioimmunotherapy from the tumor microenvironment of colorectal carcinomas Cancer Res. 67:11896-905; 2007.

52) Sodee DB, Faulhaber PF, Nelson AD, Bakale G. The prognostic significance of indium-111-capromab penetide. J Clin Oncol. 22:379-80; author reply 380-1; 2004.

53) Vallabhajosula S, Goldsmith SJ, Kostakoglu L, Milowsky MI, Nanus DM, Bander NH. Radioimmunotherapy of prostate cancer using $90 \mathrm{Y}-$ and $177 \mathrm{Lu}-$ labeled J591 monoclonal antibodies: effect of multiple treatments on myelotoxicity. Clin Cancer Res. 11:7195s-7200s; 2005.
54) Groves AM, Win T, Haim SB, Ell PJ Non[18F]FDG PET in clinical oncology Lancet Oncol. 8:822-30; 2007.

55) Behr TM, Jenner N, Radetzky S, Béhe M, Gratz S, Yücekent S, Raue F, Becker W. Targeting of cholecystokinin-B/gastrin receptors in vivo: preclinical and initial clinical evaluation of the diagnostic and therapeutic potential of radiolabelled gastrin Eur J Nucl Med. 25:42430; 1998.

56) Kunstler JU, Veerendra B, Figueroa SD, Sieckman GL, Rold TL, Hoffman TJ, Smith CJ, Pietzsch HJ. Organometallic 99mTc(III) ' $4+1$ ' bombesin(7-14) conjugates: synthesis, radiolabeling, and in vitro/in vivo studies. Bioconjug Chem. 18:1651-61; 2007.

57) Tatsch K, Schwarz J, Mozley PD, Linke R, Pogarell O, Oertel WH, Fieber RS, Hahn K, Kung HF Relationship between clinical features of Parkinson's disease and presynaptic dopamine transporter binding assessed with [123I]IPT and single-photon emission tomography. Eur J Nucl Med. 24:415-21; 1997.

58) Schwarz J, Linke R, Kerner M, Mozley PD, Trenkwalder C, Gasser T, Tatsch K Striatal dopamine transporter binding assessed by [I123]IPT and single photon emission computed tomography in patients with early Parkinson's disease: implications for a preclinical diagnosis Arch Neurol. 57:205-8; 2000.

59) Catafau AM, Tolosa E. Impact of dopamine transporter SPECT using 123I-Ioflupane on diagnosis and management of patients with clinically uncertain Parkinsonian syndromes. Mov Disord. 19(10):1175-1182; 2004.

60) O'Brien JT, Colloby S, Fenwick J, Williams ED, Firbank M, Burn D, Aarsland D, McKeith IG. Dopamine transporter loss visualized with FP-CIT SPECT in the differential diagnosis of dementia with Lewy bodies Arch Neurol. 61:919-25; 2004. 
